\title{
THE STRATEGY OF OGAN ILIR DISTRICT'S OFFICE OF POPULATION CONTROL AND FAMILY PLANNING FOR ACTUALIZING THE PROSPEROUS FAMILY
}

\author{
Nurmala HAK ${ }^{1}$
}

\begin{abstract}
This research's purpose is to know how is the implementation of Family Planning by the office of population control and family planning, women empowerment and child protection, for reaching a prosperous family, balanced population growth, two healthy kids (DAHSAT) in Indralaya Subdistrict, OganIlir District, and also to know about the success that has been done by the office of population control and family planning in Indralaya Subdistrict, such as come directly to the field (jemput bola) by using dedicated car (mobilkeliling), held a family planning counseling training for health workers and village hall workers, which the goals are to be able to give good service towards family planning acceptor achievement in Indralaya Sub-district, and mainly for achievement of family planning participants that using a contraception device MKJP and NON MKJP. This research used a descriptive research method with qualitative approach, expectedly be able to examine the achieved strategy in implementation of family planning such as by family planning counseling training in Indralaya Sub-district, OganIlir District. Based on the research's result, the amount of family planning acceptors in year 2017 - 2019 showed a success attempt, this all been done by family planning counselling implementation called communication, information, and education (KB KIE) and also doing some coachings that called by the name of Tribina, Bina Balita, Bina Remaja, Bina Lansia, in Indralaya Sub-district, but in practice it is not maximally deliver good result, because of the limited number of trained counselling workers and the lacks of equipment required, the family planning counselling also has been done in parallel with Integrated Healthcare Center (Posyandu) activities and other related activites.
\end{abstract}

Keywords: Family Planning, Family Planning Counselling

\section{The Introduction}

In order to actualize the demography and family planning development mission, which is achieving the development of insightful demography and create a prosperous happy small family, therefore one of a strategy is increasing the tenacity and prosperity of family by doing family coaching (BKB, BKR, and BKL), which are for family, teenager, elderly person, for the preparation in family life, in order to increase family revenue through The Prosperous Family Revenue Increasing Effort (UPPKS).

The success of national demography and family planning program can not be separated from the role of all working partners and stakeholders. Advocacy and communication, information, and education delivery, which has been done continuously, needs to be retained.With the release of President Decree Number 8 Year 1970, the National Demography and Family Planning

1 Fakultas Syariah dan Hukum UIN Raden Fatah Palembang, Email: nurmalahak_uin@radenfatah.ac.id 
Agency was created (formerly National Family Planning Coordination Agency) which is shortened to BKKBN.

National Family Planning Program is one of the programs for increasing the quality of demography, human resources, health, and social prosperity, which has been implemented so far by doing birth control, marriage age maturity, increase family tenacity and family prosperity. (BKKBN, 2019). Based on Article 56 Subsection (1) Act Number 52 Year 2009, BKKBN has duty to implement population control and organize family planning. Family Planning Program so far has succeed lowering the birth rate, changing public's view towards children value and family prosperity for establishing NKKBS (Prosperous Happy Small Family Norms). This situation is corresponding to new paradigm, family planning program according to GBHN (State Direction Grand Plan) 1999 with Quality Family Vision 2015.

Quality Family is Prosperous, healthy, developed, and independent family, has ideal number of children, future knowledgeable, responsible, harmonic and pious towards The One Almighty God. In the new paradigm, family planning program is very focused on the importance of reproductive rights respect effort, as an integral effort in increasing family quality (BKKBN, 2008).In order to create a quality family, a family must plan a certain age to marry, number of children and gap between children's birth, and other needs that suitable with eight family functions, which are fulfilling needs of food, education, housing, health, economy, social, culture, religion, and affection, by doing family planning and limited number of children (duaanakcukup). Hopefully the family functions mentioned will be able to create a prosperous family. At first, children's number limitation is called "duaanakcukup", but starting from January 2019, it is changed to DAHSAT (duaanaklebihsehat).

Family planning is an action which help individual or married couple to prevent unwanted birth, get the desired birth, adjust birth intervals, birth time control in comparison with couple's age, also decide number of child in a family, besides that, family planning has become one of the most basic health service and primary for women. The upscale and the spread of family planning service, hopefully can reduce a high number of sick and death of mother. In choosing a contraception method, a women should consider numerous factors including their health status, a method's side effects, unwanted birth consequences, couple's cooperation, and culture norms regarding ability to bear children.

With regard to the BKKBN guidance and guidance program in the field of family planning, it was found that the results of research stated that BKKBN implemented five programs which were socialized to the community. The five programs are maternal and infant health, family development for toddlers, youth family development, elderly family development and family planning programs. This program aims to improve the welfare of the community for the better in the future (Harahap, 2019).

In Panjaitan's research regarding contraceptive tools / drugs, it was found that the planning for contraceptive tools / drugs did not use a formula that was in accordance with the BKKBN regulations so that contraceptive device / drug delivery could be done more than once a year. The management of contraceptive tools / drugs in the BKKBN of North Sulawesi Province is not efficient and is in accordance with BKKBN regulations (Panjaitan, 2014). 
Therefore, the main topics of this article is about How's the concept of prosperous family according to Islamic law and society view in general, and also how's the strategy from OganIlir District's Office of Population Control and Family Planning for Actualizing the Prosperous Family in Indralaya Sub-district.

\section{Research Methods}

The method used for gathers data needed in this article, is using purposive sampling method, which is a certain sample has been chosen based on certain characteristics. In this article, the sample was taken from the development of number from family planning acceptor participant, from 2017 to 2019, as an active participant in family planning program at OganIlir District's Office of Population Control and Family Planning.

Kind of data needed in this article is descriptive analysis, which is explaining objects as is, matching with founded reality and data.By finding physical evidences through documentary study and understand a meaning of phenomena, the research predicts that qualitative research is the right thing to do for researched problem, because there are collected documents which has a connection with phenomena and some active informants that still in the job.Related with that, it also explained about ideas that related with discussed problems, about strategy from OganIlir District's Office of Population Control and Family Planning for Actualizing The Prosperous Family in Indralaya Sub-district, seen from theories and available thoughts. From these analysis, conclusion is obtained.

\section{Discussion and Results}

OganIlir District's Family planning and women empowerment agency vision was compiled based on a goal of increasing human resource quality as mandated by Act number 51 year 2001, in line with BKKBN performance goals, which is now called National demography and family planning agency, therefore the agency's (KBPP) vision is "BALANCED DEMOGRAPHIC GROWTH AT YEAR 2015 ALONG WITH ACTUALIZATION OF GENDER EQUALITY AND CHILDREN'S PROTECTION". The mission of OganIlir District's KBPP is : Establishing Development of Knowledgeable Demography and Creating Prosperous Happy Small Family.

Islam is allowing children's birth gap adjustment, where husband and wife do coitus which is called 'azl. 'Azl had been done by companion of the prophet Muhammad PBUH. But, this action was not get prevented or banned by Prophet Muhammad PBUH, even when this action has been heard directly by Prophet Muhammad PBUH, he still not banned the action (Muslim Narrative Hadith Number 1440), and also there's another hadith that explained about 'azl which were narrated by Imam Bukhari Number 5208, where the goal is give some gap between births. A mother that has too narrow birth gap, could affects a mother's health. Because of that, Islam allow this practice for the purpose of keeping well benefits for a mother.

Next, islam is constantly nurture a child quality, not only in a physical side, but also other sides, so that all needs that must be provided towards a child will be met, so the parents responsibility is crucial for a child's future 
and offspring. As described in Al-Qur'an, Surah At-Tahrim : 6, "Protect Yourself and Your Family from the Hellfire."

This verse explain about the importance of protection is depend on a child's parents, does a child will follow a Christian teachings or majus teachings or any other religion. Therefore, the role of parents is crucial for a child's future.

According to Act Number 52 Year 2009, family planning is an effort for arrange child birth, in-between child birth gap and ideal age for child birth, arrange birth through promotion, protection, and assistance, that fits the reproductive rights for actualize a quality family. Hence, public needs coaching by family planning workers, given understanding, counseling and coaching, also knowledges aboutfamily planning, including counselling about the usage of contraception devices, so that public can choose device and method that fits with their needs and effective for a long period of time (Sofyan, 2019).

The program mentioned before is not easy to implement, because there are still some obstacles faced by family planning workers, like some of the workers has not been following family planning counselling coaching. Even though that the ability to do tasks in family planning field is crucial. As for the steps has been taken by population control and family planning office, those are implementing some activities. activity names are for examples are Genre, Lansia, and Tri Bina. These activities done are effective as a control attempt in population growth. Because, if number of children in a family is not controlled, it will affects country's population growth. Increasing yearly population growth will become a distinctive problem for world, including Indonesia. Many problems faced by a country as a result of uncontrollable population growth. Indonesia as a developing country in south east asia has high population growth yearly. This phenomenon puts Indonesia as fourth largest population in the world, after China, India, and United States of America.

Oganilir district is one of districts under the province government of south Sumatra. This district has its own population control and family planning office. In carrying out its main duty and functions, many efforts has been done by the office, one of them is "Program Jemput Bola". This program has been done through mobile services, usually by using a certain vehicle like a car provided, which done routinely twice a week and followed by counselling by trained midwife. The midwife has given a workshop before by south sumatra's national demographic and family planning agency. With this "Program Jemput Bola", it is hoped that it will reduce child birth, especially for young married couple.

The success of population control and family planning office oganilir's district in ability to reduce birth rate is anticipated. Many bad effects will happen if population growth rate is uncontrollable. Consideration towards state's budget, education, health, food availability and limited employment, will be a serious problem. By reducing the number of children in a family, it is hoped that it gives a good result in social, economy, education, and health in a family. So it will affects, not just government program's success, but also affects all Indonesian family, as the smallest group in a nation.

Running programs of family planning and prosperous family in OganIlir's District has been a duty from the office of population control and 
family planning oganilir district. With the fulfillment of education needs, social, economy, health, and other needs in a family, it is hoped that a family will get along well, in harmony, and prosperous.

Parallel with government goal in running family planning program which is forming a prosperous happy small family, also in line with the goal of marriage according to Islamic law, such as create a Sakinah mawaddahwarahmah marriage's life (Abdurrahman, 1995: 114).

As mentioned in Al-Qur'an Surah Ar-Rum verse 21: "And one of His signs is that He created for you spouses from among yourselves so that you may find comfort in them. And He has placed between you compassion and mercy. Surely in this are signs for people who reflect."

According to HuzaimahTahidoYanggo as quoted by Tihami and SohariSahrani, an ayat mentioned before has a meaning that Islamic family was created by the result of cohesiveness between serenity (Sakinah), loveful (Mawaddah), and affection (rahmah) (Tihami. \& Sahrani, 2014). One of the power of Allah SWT is that human are created in pairs with another human. Also created between them are mawaddah and rahmah. Because a man marries a woman because of love and affection to her, then having a child from her. And also because a woman needs a man and pleased towards him (Quthb, 2004).

In an Act number 10 year 1992 about demography development and prosperous family building, family planning is an effort of increasing concern and public's role through marriage age maturity, birth control, family tenacity coaching, and increasing family prosperity to creates prosperous happy small family (BKKBN, 2008)

For a realization of family planning program, fertile age couple should have healthy reproductive habit's pattern, which by plan and arrange birth at safe period and good health level. This knowledge about the pattern could be achieved at family planning activities. Of course, it will needs skill and knowledge that connected with how to arrange pregnancy gap and birth gap which would be get from family planning counselling. Therefore, every family planning acceptor will get useful knowledge in following family planning program.

According to World Health organization, family planning is an action which helps individual or married couple to prevent unwanted pregnancy, to get desired child birth, to arrange birth interval, to control time of birth in comparison with married couple's age, and to decide number of children in a family, besides family planning has become one of basic and primary health care for women.

Can be understood that in a beautiful marriage's life, it should be full with reciprocal affection. So that it will achieve mawaddahwarahmah, for reach happiness in the world and in the hereafter.Also, with a limited number of children, it will be easier for a family to create prosperous happy small family or in islam is called Sakinah mawaddahwarahmah.

Indonesia's law clearly regulated for fulfillment of obligatory in a family's life. Article 34 subsection I Act Number 1 year 1974 mentioned "a husband is obligated to protects his wife and gives every marriage's life needs corresponding to his capability." 
The effort from the office of population control and family planning at oganilir's district is needed to create a prosperous happy small family or based on a concept in Islamic law which is Sakinah mawaddahwarahmah family in oganilir's district society. Related to how's the strategy of office of population control and family planning at oganilir's district in accordance with its programs are trying to create a prosperous family in indralaya subdistrict. These strategies are done according to Ahmad Ali are a measurement to tells how a regulation are obeyed or not (Ali, 2010: 375).

A strategy is a measurement for how effective an output level, policy and procedure of an organization to reach its approved goals (Merrynce. \& Hidir, 2013: 44). Related to article topics, strategy is used to measure how far OganIlir District's office of population control and family planning for reach a goal by doing its duty so it'll capable to creates prosperous family in indralaya sub-district society. The discussion of article problem is done so that there is an understanding in learning and doing, clear thought frame is needed. The thought frame is written in diagram as contains in figure 1:

Figure 1. The thought frame

\begin{tabular}{|c|}
\hline \multicolumn{2}{|c|}{ Population Growth } \\
\hline Family Planning Program \\
\hline $\begin{array}{c}\text { Strategy of Population Control and Family } \\
\text { Planning Office OganIlir District }\end{array}$ \\
\hline Prosperous Family \\
\hline
\end{tabular}

The figure above has shown that how is the process to actualizing prosperous family through family planning program, which had been done by population control and family planning office, especially for indralaya subdistrict society.

In pressing number of population growth, effort from office mentioned is crucial through family planning program, so that it will creates a prosperous happy small family, or based on Islamic law concept, a Sakinah mawaddahwarahmah family for indralaya's society in oganilir district.

By using normative approach and juridical approach, these approaches are based on Aqedah or Islamic norms which also based from $\mathrm{Al}-$ Qur'an and Hadith. These approaches are useful for examine family law especially about birth control seen from syara' perspective. The discussion about the strategy of oganilir district population control and family planning office, such as doing "jemput bola" via mobile family planning's car, doing public service through public health center, integrated healthcare center, and held an event like family planning counselling which located in indralaya sub-district, oganilir district.

As described in background that in this discussion, there are steps which has been taken by population control and family planning office to increase public knowledge and understanding on family planning, such as attend workshops regarding implementation of family planning counselling in indralaya subdistrict, oganilir district. These actions are taken to overcome problems such as lacks of family planning field officer (PLKB), because 
existing officers are not solely family planning officer only, they also had another job and this situation are known by head of office. Also there is lacks of trained counselling workers, and lacks of infrastructure to implement family planning counselling. Despite the condition, family planning service activity still run well, by approaching public directly. As for steps that has been taken to reach success are by doing planning, organizing, implementing and supervision, so that every moves and steps are well organized.

It is known that implementation of family planning counselling program which has been planned are: increase quality of family planning counselor, procurement of counselling infrastructure or KIE kit, and budget availability for family planning counselling which now enough for only two kinds of contraception device such as IUD and male medical procedure. Therefore, for this year, the budget will have some addition for counselling and implant contraception device. The counselling which will be given to public is suitable with the principles of counselling such as : time period and age for marriage, time for child birth, appropriate time for stopping fertility, way of pregnancy and healthy birth, and family planning and health service place and kinds of contraception devices like pill, injection, implant, condom, AKDR, MOP, MOW for every good and bad of them. Counselling activities are carried out face to face and used props like KIE Kit and KIE ABPK, and attempted to do good counselling steps. Family planning program implementation carried out and oriented on planned goals including family planning counselling activities. Family planning implementation plan has written in RENSTRA year 2010-2015, including nowadays by family planning and women empowerment agency of oganilir district, that vision and mission of family planning and women empowerment agency of oganilir district is to increase family planning officer performance, to provide facilities and infrastructures needed for increasing family planning service quality, to increase quantity and quality of family planning acceptor, and to broaden public knowledge about family planning and reproductive health.

To increase family planning officer performance, every year family planning officers are included in workshops held by research and development division from national demography and family planning agency of south Sumatra province. Those workshops are attended by family planning field officer or head of UPTB (which also concurrently positioning as PLKB), and by medical personnel like midwife and doctor.

“... efforts to increase family planning officer quality always implemented gradually, as was done the previous years, this year we planned and prepared officers name who will attend workshop at national demography and family planning agency of South Sumatra Province, for PLKB (including head of UPTB) will follow counselling workshop, refreshing, $\mathrm{R} / \mathrm{R}$ clinic, family in harmony, and family tenacity buildings. As for our medical workers, we already asking officers name which will be trained ti head of public health center in districts through head of UPTB KBPP, a training that will be attend those which among them are ABPK Counselling, R/R Clinic, IUD Implant insertion, and device-less Vasectomy (for doctor)”.

".... Decision-making tools (ABPK) is not the only deciding factor that determine family planning counselling success, because of it only help public understanding. The most important factor is ability or potention of officer in 
implementing family planning councelling and time availability in implementing family planning counselling."

The number of officers which had been attended counselling workshop at national demography and family planning agency of south Sumatra province are 8 people. Here are the names of midwife who had been attended the workshop at PKM Indralaya District, as shown in table 1.

Table 1. The names of midwife who had been attended the workshop at PKM Indralaya District

\begin{tabular}{|l|l|l|l|l|}
\hline No. & Name & NIP/NRPTT & Location & Date \\
\hline 1. & Hj. Gita Soraya & 196804081988032002 & PKM Indralaya & $22-24 / 3-2011$ \\
\hline 2. & Titin Asqorina & 198312112006042006 & PKM Indralaya & $01-05 / 3-2011$ \\
\hline 3. & Sari Aprilia & 198604242009032011 & PKM Indralaya & $13-17 / 4-2012$ \\
\hline 4. & Hj. Fatimah & 196712161988122002 & PKM Indralaya & $4-9 / 11-2012$ \\
\hline 5. & DesieYulita & 197712172007012008 & PKM Indralaya & $\begin{array}{l}29 / 10-2012 \\
\text { sd. 2/11-2012 }\end{array}$ \\
\hline 6. & Sri Aprianti & 197704152007212005 & $\begin{array}{l}\text { Sakatiga } \\
\text { Seberang }\end{array}$ & $21-25 / 9-2012$ \\
\hline 7. & Sri Ermini & 197305281993012001 & $\begin{array}{l}\text { PKM } \\
\text { TalangAur }\end{array}$ & $1-5 / 4-2011$ \\
\hline 8. & Zeni Maria Ulpa & 2004816741 & SudiMampir & $13-17 / 4-2012$ \\
\hline
\end{tabular}

Source : public health office of oganilir district 2017

“.... Midwives that had been attended family planning counselling workshop at national demography and family planning agency of south Sumatra province are 8 people, this year we proposed two more people, because every year the agency allocated 2 people for counselling workshop, two people for IUD insertion training and two more people for R/R clinic."

Data below are based on year 2018 and 2019, which as shown in table 2 and 3 :

Table 2. Data of family planning acceptors, Indralaya District year 2018

\begin{tabular}{|c|c|c|c|}
\hline No. & $\begin{array}{l}\text { Fertile } \\
\text { Couple }\end{array}$ & Contraception & Month/Year/Explanation \\
\hline 1. & 6074 & $\begin{array}{l}\text { IUD Acceptors = } 710 \\
\text { MOW Acceptors = } 118 \\
\text { MOP Acceptors = } 16 \\
\text { Implant Acceptors = 951 } \\
\text { Injection Acceptors = } 1258 \\
\text { Pill Acceptors = 961 } \\
\text { Condom Acceptors = } 341 \\
\text { Total = 4355 } \\
\text { Remain = } \\
\text { Participate) }\end{array}$ & $\begin{array}{l}\text { December } 2018 \\
\text { Explanation = Reasons of } \\
\text { Not Participating } \\
\text { a. Pregnant = } 119 \\
\text { b. Want to have child } \\
\text { immediately = } 664 \\
\text { c. Want to have child } \\
\text { in near future }=572 \\
\text { d. Not wanting } \\
\text { children anymore = } \\
364\end{array}$ \\
\hline
\end{tabular}

Source : result recap of Acceptors from family planning indralaya district year 2018 
Table 3. Data of family planning acceptors, Indralaya District year 2019

\begin{tabular}{|c|c|c|c|}
\hline No. & $\begin{array}{ll}\text { Fertile } & \text { A } \\
\text { Couple } & \\
\end{array}$ & Contraception & Month/Year/Explanation \\
\hline 1. & 6185 & $\begin{array}{l}\text { IUD Acceptors }=748 \\
\text { MOW Acceptors = } 118 \\
\text { MOP Acceptors = } 16 \\
\text { Implant Acceptors = 973 } \\
\text { Injection Acceptors = } 1287 \\
\text { Pill Acceptors = 961 } \\
\text { Condom Acceptors = } 325 \\
\text { Total = 4428 } \\
\text { Remain = } \quad 1751 \quad(\text { Not } \\
\text { Participate) }\end{array}$ & $\begin{array}{l}\text { December } 2019 \\
\text { Explanation = Reasons of } \\
\text { Not Participating } \\
\text { a. Pregnant }=115 \\
\text { b. Want to have child } \\
\text { immediately = } 683 \\
\text { c. Want to have child } \\
\text { in near future }=587 \\
\text { d. Not wanting } \\
\text { children anymore = } \\
372\end{array}$ \\
\hline
\end{tabular}

Source : result recap of Acceptors from family planning indralaya district year 2019

Based on data above, it is known that acceptors target achievement which using MJKP (IUD, MOP, MOW, and Implant) are 5408 acceptors, the number of non MJKP are 6939 Acceptors (based on overall of active family planning acceptors achievement seen at year 2017, 2018, and 2019). So, the conclusion is family planning acceptors achievement that using MJKP are $35 \%$ and Non MJKP are $45 \%$. Also $20 \%$ are not participating in family planning.

\section{Conclusion}

The concept of prosperous family, like children's birth gap adjustment,is in accordance with Islamic law and teaching. Doing birth gap adjustment is one of ways to reach sakinnahmawaddahwarahmah family.Not just for the parent's health, but also for children's health as well. Population control, family planning, and women empowerment office at indralaya subdistrict, oganilir district already done many things to maximize family planning program. The number of acceptors which participate in family planning has increase from year to year. The office has done some provision like in marriage age, amount and method of conceive a child, and also implementing the 8 functions to achieve quality family towards prosperous family.Balanced population growth is seen from fertile age couple that participate in family planning program, also services to poor family free of charge. And also doing ways such as GENRE, PUP (Marriage age postponement), LANSIA (Elderly), and TRI BINA. Internal and external supervision from province and national level, has been done routinely twice a year, while external supervision has been done by BPKP and WASNAL, usually comes to monitor family planning program at the end of the year. 


\section{References}

Abdurrahman. (1995). Kompilasi Hukum Islam di Indonesia. Akademika Pressindo.

Ali, Ahmad. (2010). Menguak teori hukum dan teori peradilan. (Vol I). Kencana.

BKKBN. Sejarah BKKBN. https://www.bkkbn.go.id/pages/sejarah-bkkbn

Harahap, Erfina Noviyanti. (2019). Pembimbingan dan pembinaan BKKBN dalam bidang keluarga berencana di Kecamatan Siantar Barat Kota Pematang Siantar. Jurnal Pemberdayaan Masyarakat, 7(2), 128-144. http://dx.doi.org/10.37064/jpm.v7i2.5828

Merrynce. \& Hidir, Ahmad. (2013). Efektivitas pelaksanaan program keluarga berencana. Jurnal Kebijakan Publik, 4(1), 43-50. http://dx.doi.org/10.31258/jkp.4.01.p.43-50

Panjaitan, Ruth Margaretha. (2014). Pengelolaan obat Keluarga Berencana (KB) di Badan Kependudukan Keluarga Berencana Nasional (BKKBN) Provinsi Sulawesi Utara. Pharmacon, 3(3). https://doi.org/10.35799/pha.3.2014.5388

Quthb, Sayyid. (2004). Tafsir fi zhilalil-qur'an. (Jilid 17). GemaInsani.

Renstra Badan KBPP Kabupaten Ogan Ilir Tahun 2010

Tihami \& Sahrani, Sohari. (2014). Fiqh munakahat. PT Raja GrafindoPersada.

Yayasan Penyelenggara Al-Qur'an. Al-Qur'an dan terjemahannya. Cv. Toha Putra. 